\title{
Editorial: Primitive art, early art or no art at all?
}

\author{
HENK WES SELING \\ NIAS, Wassenaar, The Netherlands
}

On 20 June 2006 a new museum in Paris opened its doors for the first time, the Musée du Quai Branly. President Jacques Chirac inaugurated the museum in front of an audience that included, among others, UN Secretary General Kofi Annan and France's most famous anthropologist Claude Lévi-Strauss. The museum is another enrichment of that fabulous city, already so well endowed with museums and monuments.

The Fifth Republic, founded by General de Gaulle in 1958, has been extraordinarily successful in the creation of new museums. De Gaulle himself did not feel the need to have a special museum built in order to commemorate him. He may have thought that he would be remembered anyway, and he was right. But he certainly stimulated French culture and had Paris embellished in many respects. His famous Minister of Culture André Malraux not only ordered the cleaning up of the blackened façades of many Paris monuments and other buildings, but also actively stimulated cultural activities outside Paris or, as the French say, in the provinces. Malraux also took a great interest in non-Western art and in this way helped the founding of the Quai Branly museum. De Gaulle's successor, Georges Pompidou, was of course the source of inspiration for the Museum of Modern Art, also known as the Centre Pompidou and particularly famous for its revolutionary architecture. Another less extravagant but also rightly famous building is the Institut du Monde Arabe which dates from the late 1980s and was built by Jean Nouvel, the architect who also built the Quai Branly Museum.

Pompidou's successor, Valéry Giscard d'Estaing, had the Gare d'Orsay transformed into the Musée d'Orsay, the centre of 19th century art and glorious home of the French and other impressionists. The greatest builder of them all was France's first socialist president, François Mitterrand. Of his many projects, known as the 'Grands Travaux', the most impressive was the Grand Louvre and the most controversial was the new great library, the Bibliothèque Nationale de 
France. Mitterrand loved to walk through Paris and regarded himself as a master builder. He was fond of the Egypt of the pharaohs, which had developed his favourite architectural shape, the pyramid - a design which, despite great controversies and strong opposition, he had constructed in the great cour of the Louvre.

Thus, it goes without saying that President Jacques Chirac also wanted to be remembered as the founder of a museum. A true connoisseur and amateur of what used to be known as primitive art, if not the art of primitive peoples, he decided in 1996 to have a museum built for these art forms as a lasting legacy of his presidency. As the phrase 'primitive art' was of course unacceptable - the only primitive artists we still know today are those great painters such as Jan van Eyck, Hans Memlinc, Pieter Bruegel and others known as the 'Flemish primitives' - a more acceptable word had to be found, and so the term 'arts premiers' (early arts) was born. It was observed that some of this art is not early or old at all. In order to avoid such semantic discussions the museum simply took the name of its location: Musée du Quai Branly.

The museum is dedicated to African, Asian, Oceanic and American civilizations, has a surface of 9000 square meters, and houses about 300,000 objects, of which only a little over one percent is on display. Of course the museum, both the building and the collection, have been criticized. How could it not be in this postmodern world? It has even been labelled 'A Heart of Darkness in the City of Light'! This did not prevent the museum from becoming an overnight success. The same is true for its restaurant, Les Ombres, which has a great view of the Eiffel Tower and has already become a culinary hotspot (it is necessary to book a table two weeks in advance).

The collection of the museum is based on those of two former Paris museums, the famous Musée de l'Homme which formerly was located in the Palais Chaillot and the less well known but very interesting Musée des Arts d'Afrique et de l'Océanie (MAAO) at the Porte Dorée, which was housed in the building that was constructed for the great colonial exhibition of Vincennes held in 1931. The merger of the two collections into the new one, and the disappearance of the two museums, did not take place without some opposition. In particular, the Musée de l'Homme fought the presidential decision tooth and nail. The 'guerre des musées' was a war about principles and therefore a bitter one. It was not only a matter of a new building but also of a new approach. Artefacts from non-European civilizations are mostly to be found in former colonial museums (like the MAAO) or anthropological museums (like the Musée de l'Homme). Their approach was scientific and educational. The approach of the Quai Branly Museum is purely aesthetic. It is simply a museum of non-Western art, based on President Chirac's conviction that there is neither a hierarchy among peoples nor among arts and cultures. 
Of course, the aesthetic approach to primitive (or early) art is not entirely new. Since Picasso, European artists have been inspired by art from Africa (Picasso himself as well as Giacometti, the painters of the Die Brücke group and others), from Polynesia (Kokoschka) and elsewhere. André Malraux wanted to have the art collections of the anthropological museums moved to the national art museums in order to underline their aesthetic value. There is however something problematic with the purely aesthetical approach to non-Western art. The first time I realized this was when visiting the great exhibition about African art held in London in 1995. While admiring the artefacts on display I could not help asking myself two questions: Is it art? Is it African?

Africa as a concept didn't exist before Europeans invented it, neither did America or Asia, for that matter. America was named after an Italian explorer. Asia and Africa were the names of Roman provinces that contained, respectively, parts of the Near East and North Africa. For Arabs also, 'Africa' simply meant North Africa. The land below it was named the Sudan (Bilad al Sudan: Land of the Blacks). The exhibition wanted to present Africa as a cultural unity and thus to overcome our western ethnocentrism, but in the final analysis, it was itself based on the Eurocentric vision which is at the basis of the very concept of Africa itself.

Another problem is the notion of art. As I read somewhere, there is no word for art in any of Africa's thousand or so languages. Of course, as Molière pointed out, one can speak prose without knowing it and by the same token people can make art without having a word for it, but to apply the notion of art to all sorts of artefacts is somewhat confusing. The London exhibition, for example, exhibited the oldest human artefact, a hand axe from one and a half million years ago. One can admire it, but hardly consider it as art in the usual sense of the word.

The same goes for the treasures of the Musée du Quai Branly. There are items such as chairs and seats, doors and pulpits, clothing, vases, pots and more, such things that we normally describe as crafts rather than art. On the other hand, there are also many statues. Statues we know from Western art, but again there is a difference. The only information given about those statues concerns the region of origin and the time when the pieces were probably made. Apparently, nothing more is known. This, too, is strange. In Europe, we generally know - al least from the 14 th/15th century onwards - the name of the maker, when and where he (or she, but that is the exception) lived, what the work of art represents (if anything), who is being portrayed, which landscape it is, or which biblical or mythological story it depicts. Here, however, we know nothing. What you see is what there is.

Thus, after a while, the idea of visiting a museum of art disappears. Not because there are no objects that engender an experience of beauty. There are certainly such objects, and in the formulation from my old schoolbook, which is as effective 
as it is simple, where art was defined as 'the making of beautiful things', we can thus speak of art. But I cannot help thinking that it is something rather different from what we normally understand by this word. This is not to say that the Musée du Quai Branly is disappointing. On the contrary, the museum is an exciting and impressive demonstration of the many forms of the creativity of the human race, sometimes also including art. 